\title{
The adolescent's perceptions and reasons for enjoyment at physical education classes in four elementary Brazilian schools
}

Authors' Contribution: A Study Design B Data Collection

C Statistical Analysis D Data Interpretation

E Manuscript Preparation

$\mathbf{F}$ Literature Search

G Funds Collection
Vanilson Batista Lemes ABCDEFG, Caroline Brand ABCDEF, Camila Felin Fochesatto ABCDEF, Adroaldo Cezar Araujo Gaya ABCDE, Anelise Reis Gaya ABCDEF

Project Esporte Brasil (PROESP-Br), School of Physical Education, Physiotherapy, and Dance, Federal University of Rio Grande do Sul, Porto Alegre, Brazil

\section{abstract}

Background: This study aimed to describe adolescents' positive and negative perceptions and reasons for enjoyment in physical education (PE) in four schools, and to identify adolescents' opinions about possible improvements in PE classes.

Material and methods: This is a descriptive cross-sectional study, with a qualitative approach. The sample was composed of 240 girls and 230 boys, aged between 11 and 17 years according to exhaustion criteria, which is a requirement for the analyses of content. Perceptions and reasons for enjoyment in PE were evaluated according to three open questions. Analysis of content was applied.

Results: There were different positive perceptions between schools related to sports enjoyment. Negative perceptions were mainly related to the teacher-student relationship, not having PE, and teachers' work methodologies. Suggestions were focused on diversifying specific physical activities, exercises, and sports.

Conclusions: Adolescents enjoy PE due to fun, learning, liking physical activity practice, exercise, and sports. Negative perceptions were related to the difficulty with the teacher and not having PE classes. Adolescents suggest that they would like to have a wide variety of types of physical activity, physical exercise, and sport modalities.

Key words: sports; physical activity; motivation; physical exercise.

\section{article details}

Article statistics:

Full-text PDF:

Copyright

Indexation:

Funding:

Conflict of interests:

Corresponding author:

Open Access License:
Word count: 3,021; Tables: 5; Figures: 0; References: 46

Received: July 2020; Accepted: October 2021; Published: December 2021

http://www.balticsportscience.com

Gdansk University of Physical Education and Sport, Poland

Celdes, Clarivate Analytics Emerging Sources Citation Index (ESCI), CNKI Scholar (China National Knowledge Infrastructure), CNPIEC, DOAJ, EBSCO - Central \& Eastern European Academic Source, EBSCO - SPORTDiscus, EBSCO Discovery Service, Google Scholar, Index Copernicus, J-Gate, Naviga (Softweco, Primo Central (ExLibris), ProQuest - Family Health, ProQuest - Health \& Medical Complete, ProQuest - Illustrata: Health Sciences, ProQuest Nursing \& Allied Health Source, Summon (Serials Solutions/ProQuest, TDOne (TDNet), Ulrich's Periodicals Directory/ ulrichsweb, WorldCat (OCLC)

This research received no specific grant from any funding agency in the public, commercial, or not-for-profit sectors. Authors have declared that no competing interest exists.

Vanilson Batista Lemes (vanilson.lemes@hotmail.com). Street: Felizardo, 750. Neighborhood: Jardim botânico. 90690200 City: Porto Alegre- Brazil. Phone: +55 (51) 33085883

This is an open access article distributed under the terms of the Creative Commons Attribution-Non-Commercial-NoDerivatives 4.0 International (https://creativecommons.org/licenses/by-nc-nd/4.0/), which permits use, distribution, and reproduction in any medium, provided the original work is properly cited, the use is non-commercial and is otherwise in compliance with the license. 


\section{INTRODUCTION}

Physical Education (PE) at school is one of the most important settings to develop interventions to increase physical activity (PA), and positive health indicators in adolescents [1-3]. PE is the only opportunity for some students to learn and practice sports, gymnastic, games, dance, exercise and healthy lifestyle habits [4-6]. Some studies approach the PE model planned for health promotion and for increasing moderate and vigorous physical activity (MVPA). This PE model improves motor performance, fitness levels, well-being, health indicators, and quality of life [3, 7-13].

However, individual adolescent preferences can exert an impact on reasons for enjoyment and perceptions about PA and PE [14-20]. These subjective variables can be barriers or facilitating factors to effective participation in PE classes at school. For example, adolescents with high body mass index (BMI) present barriers to major enjoyment in PE classes [14]. Also, for these adolescents, the traditional and rigorous PE classes lead to lower positive perceptions than for adolescents with normal BMI [14]. Another important aspect is that group PA or sports classes at school can be difficult to enjoy by these adolescents [14]. Boys with adequate standards of BMI presented fewer barriers in PA and PE than girls and adolescents with overweight or low self-esteem [17-20]. The same situation can happen due to self-esteem changes in adolescence transition, for girls mainly [15-17].

Studies regarding this topic mainly focus on explaining the reasons why adolescents present negative perceptions or low enjoyment during PE classes [15-20]. This evidence presents how higher levels of motor competencies and motivational behaviors are associated with positive perceptions and high enjoyment in PE, and how they positively affect the MVPA $[18,21,22]$.

Despite that, there are few studies in Brazil aimed to understand how adolescents perceive $\mathrm{PE}$ according to a real and practical opinion. The adolescents' view about their classes is highly important to develop and diagnose pedagogical strategies to lead them to enjoy PA and PE [23-26]. Brazilian studies suggest that most differences in PE perceptions have a limited view [27-32]. It is often reported due to divergence of gender behaviors or group factors. Studies pointed that boys prefer sports competitions, while girls intrinsically like $\mathrm{PA}$, aesthetic and individual exercise, as gymnastic and dance [27-32]. Additionally, the researchers present a description of general PE preferences, activities that adolescents like the most, and comparisons by gender [17-20, 33]. The applied methods are questionnaires that express an arbitrary index or numeric classifications [17-20, 33-35].

However, we understand that personal preferences for enjoyment in PE could be observed independently of these previous subgroup classifications. It is not mentioned in the research, because these aspects cannot be measured by questionnaires with closed or numeric questions. For example, when students participate in formal school evaluations, they do not usually speak directly to teachers about personal preferences or PE enjoyment boundaries.

The present study is justified, considering the need of knowing how adolescents perceive PE classes and how they explain by means of simple open questions, once the adolescents' language comprehension is facilitated. It is necessary to understand adolescents' preferences, perceptions and reasons for enjoyment to achieve success of PE at school. Also, this research topic is little explored in the Brazilian education context. Thus, with a perspective to contribute to interventions planning in $\mathrm{PE}$ classes the aims of this study were: to describe the adolescents' positive and negative perceptions and reasons for enjoyment in physical education (PE) in four schools, and to identify adolescents' opinions about possible improvements in PE classes. 


\section{MATERIAL AND METHODS}

\section{DESIGN AND POPULATION}

This is a descriptive cross-sectional study, with a qualitative approach [36], which considered a population of 1,570 adolescents from seven public state elementary schools of Charqueadas, a city located in southern Brazil. All the Helsinki Declarations' ethical aspects were applied [37]. The evaluation methods and procedures were approved by the ethics committee of Universidade Federal do Rio Grande do Sul (number: 3.634.294). School's director, responsible teachers, adolescents, and parents signed consent terms. The identity of all participants was kept confidential.

\section{GENERAL PROCEDURES}

The study was carried out at the end of 2017 (October, November and December). Each school was evaluated during one week, approximately. All evaluations were conducted according to school hours and internal organization to minimize the researchers' interference in the adolescents' classes routine. Two researchers (one male and one female) applied the questionnaire in the respective adolescents' gender. These researchers had 5 years of experience in School Physical Education and scientific evaluations. The classes were composed of 15 to 30 adolescents, and the questionnaires were applied within 45-60 minutes. The students were requested to be as sincere as possible. The structured open questions were developed specifically for the present study context.

\section{SCHOOLS CRITERIA PARTICIPATION AND SAMPLE SELECTION}

Schools were included according to conglomerates due to different educational indexes ranged from 2.1 - 5.1 points (EIND) [38]. The EIND is an educational global level of Brazilian schools. It evaluates the students' learning and notes in the main disciplines (Portuguese language and mathematic) considering the number of approving and reproving students per school and grades [38]. An ideal level is considered as six points. It discloses the educational difficulties from the included schools [38]. In addition, to preserve the sample representativeness, the selected schools are located in four distinct city regions, and they are attended by children and adolescents from all urban city locations (Figure 1).

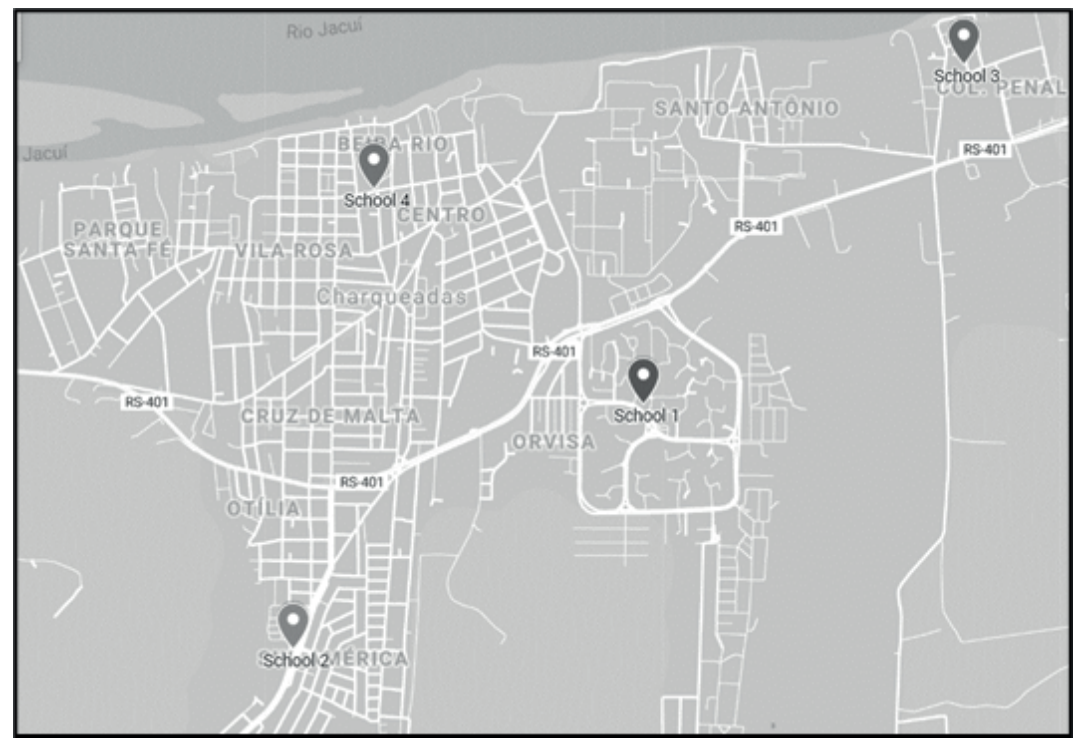

Fig. 1. Charqueadas Map and school neighborhood locations

The present adolescents sample was selected in classes of sixth to ninth grade. Thus, 240 girls and 230 boys, aged between 11 and 17 years participated of the present study. This sample size was obtained according to exhaustion criteria, which is a requirement of analyses of content $[39,40]$. 


\section{PERCEPTIONS AND REASONS FOR ENJOYMENT}

Perceptions and reasons for enjoyment in PE classes were evaluated considering the age and the maturity of learning according to the adolescents' school grade. Considering this, three short open questions were applied. The original questions were written in Brazilian colloquial Portuguese. The participants answered on a paper sheet, as follows:

1. How do you perceive your Physical Education classes?

2. What do you like most about your Physical Education classes?

3. Give some suggestions for improvement in your Physical Education classes.

\section{INFORMATION ANALYSES}

The analysis of questionnaires and the obtained information was conducted in three stages $[39,40]$.

a) Pre-analysis:

1. Representativeness: the sample was pre-established considering a school population and four different schools city regions by conglomerates, the number of recruited adolescents in each school were: school A $(n=135)$; school B $(n=145)$, school C $(n=139)$ and school D $(n=51)$, totalizing approximately $40 \%$ of all 1200 students from these four schools enrolled in elementary grades (1st to 9 th grade).

2. Exhaustion criteria: All participants' responses (470) were individually analyzed until we realizes if answers were repeated and could be organized in categories by each school.

3. Homogeneity: Participants answered the same questionnaire, and we opted for analyzing the results based on each of the students; afterwards we described the four schools' contexts to ensure homogeneity criteria;

4. Pertinence: the questions were carefully designed to match age, specific sample comprehension, and objectives of the study. Participants were guided during all questionnaires application time;

5. Exclusivity: to ensure the exclusivity of each adolescent opinion, we pre-established categories of perception about PE classes according to the material exploration stage, as follows.

\section{b) Material exploration}

In the first stage, we perceive divergent adolescents' opinions according to four school contexts. Thus, the results of this research were developed from this point of view, and two categories were established: the positive perception and the negative perception. The participant was included in one of these categories according to the exhaustion search, which showed many repetitive responses to questions 1,2 , and 3 from all questionnaires. After this procedure, we detect that some adolescents described the content of classes they most liked, according to the following categorization: Futsal or Soccer, Physical Activity, and Physical Exercise, Handball, and Volleyball, don't like or perceived negatively physical education. The question about PE improvements was summarized according to exhaustion criteria, kinds of individual reports and each of the four schools contexts. At this stage, we transcribed all questionnaires to the Excel software.

\section{c) Results development: description of categories}

According to the above-described procedures, we choose to present a synthesis of results by individual school profiles. Answers about adolescents' perceptions were summarized in categories and not by individual cases. The presentation form was selected due to providing a general profile about the four PE class contexts according to the aims of this research and according to the repeated results by each participant. Results are presented in a table, representing the four schools profiles separately. 


\section{RESULTS}

Table 1 presents the qualitative summary of perceptions and reasons for enjoyment at PE classes and suggestions about improvements. Adolescents' perception can be considered positive, and the reasons for enjoyment at PE were mainly: fun, sports, physical activity practice, and exercises.

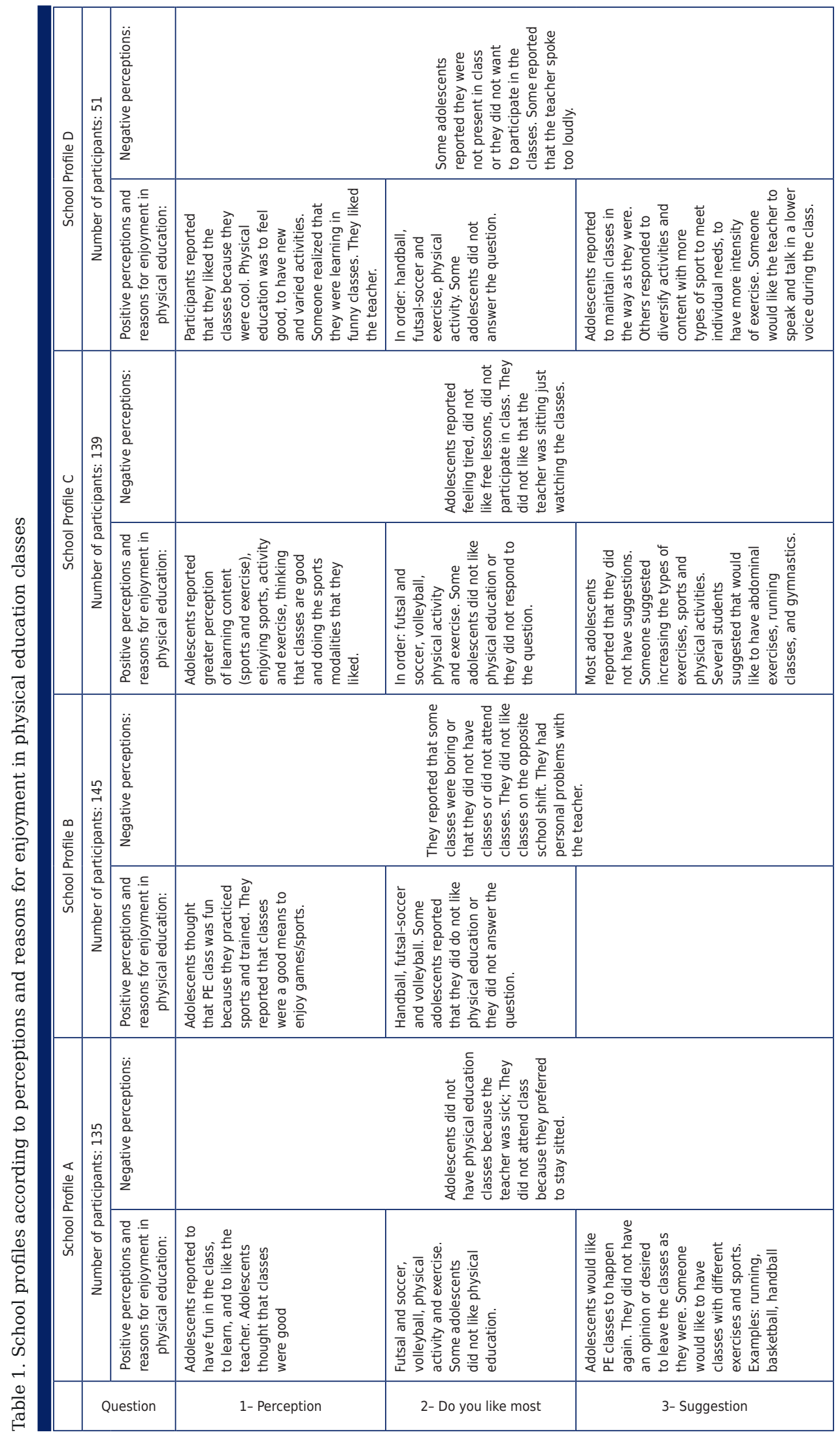


The reported negative aspects were when adolescents did not have PE classes because the teachers were out of school due to sickness, reasons associated to personal relationship with the teacher and the teacher talking loudly during classes. Some adolescents reported that they did not participate in PE classes due to a negative perception about themselves and students' groups. The question about what adolescents liked most in PE classes was answered predominantly with sports, such as volleyball, handball, futsal and soccer, and general PA - exercise. The suggestions for improvements were synthesized in increasing the variety of sports and PA types, such as dance, running, athletics classes, basketball, specifics sports training methods, gymnastics, better teaching practice and advance in teacher speak. According to school profiles A and C, students reported that they would like PE classes to happen again, indicating that they did not have PE classes at the moment of this research.

\section{DISCUSSION}

This study aimed to describe the adolescents' positive and negative perceptions and reasons for enjoyment in physical education (PE) in four schools, and to identify adolescents' opinions about possible improvements in PE classes. The main findings showed that adolescents had different positive perceptions about PE, mainly regarding the fun in sports practice. The school profile A presents the lowest conceptual positive perception. The adolescents' negative perceptions were the teacher-student relationship, not having $\mathrm{PE}$, and problems related to the work methods used by teachers. Also, the adolescents' suggestions were to diversify specific activities and exercises/sports.

The fun, innovative and diverse methods were the main positive perceptions and reasons for enjoyment in PE class. The enjoyment from sports was one of the most specific adolescents' preferences. PA and exercises, as well as the positive feelings, and well-being were reported as the reasons for enjoyment. Besides, the self-perception of learning in the class was reported as a positive aspect. In agreement with our findings, studies developed in Brazil pointed out that students had a general positive perception about PE classes. The content of the greatest interest in these studies were the sports [33, 41]. Also, when the adolescents learn from a challenge, they consider it as a positive aspect. In these cases, the teacher's feedback was an important tool that allowed an opportunity to solve problems and to have better experiences, developing a positive flow of feelings during PE classes [42].

The relationship with the teachers and the methodologies adopted by them seemed to be decisive in the adolescents' PE negative perceptions. Attitudes reported by adolescents, such as inadequate verbal methods were associated with negative feelings in classes, since they could impair the student's perception of support concerning their teacher [43]. Otherwise, behaviors such as positive feedback and praise for good performance in a given activity were associated with adolescents' positive feelings and improving the PE enjoyment [44]. As regards class methods, the study showed that positive PE climate in tasks was able to predict better attitudes towards PE and the teacher [45].

Regarding the positive perceptions mentioned by the students, in order to understand the needs and individual preferences, it is important to think about the teacher practice and rethink the methodologies. The students' opinions presented in this study reinforce this hypothesis. Also, it is important to consider the specific sports suggested and PA practices adequate to the individual profile. In addition, the teacher-student relationship once again is a key point to PE enjoyment success.

These issues were described in the literature [17], suggesting the importance of gender specific classes, too. The girls positively perceive PE classes when they have a possible choice, variety, and novelty purposing positive feelings. This reflects in teacher-student 
relationships, as mentioned in the present results. Boys mainly seems to like the competition of sports [15-22]. However, it is not a closed rule. The teacher's position in PE cannot be only as an agent of the teaching-learning process. The teacher is also a reference, an important social agent for adolescents' life transitions. The students of distinct genders perceive their relationship with the teacher as more important than their relationship with colleagues regarding constructive experiences in PE classes [46].

Our study showed a perspective to understand the student views about PE classes to improve it. Also, our findings can assist teachers to plan and execute better classes according to adolescents' enjoyment and increasing participation.

The limitations of the present study lie in the lack of interviews with students and teachers for a better comprehension of the relationship between them. It is a perspective for future research. Also, studies with complex approaches are needed to consider psychosocial variables, such as personality traits, students' origin, body weight, satisfaction with personal appearance, and peer group relationships. From this, we understand that an improved relationship between teachers and students is an essential aspect of PE enjoyment for both parties. These human relations are much more profound than our study achieved; it delimits the present design as a descriptive study.

Additionally, the students who perceived PE classes positively seem to be those who had the best relationship with their teachers. Also, they apparently had PE classes with diversified activities and sports, in addition to innovations. Thus, we reinforce that the teacher is responsible for most of the student's positive or negative perceptions, as well as for planning strategies and methodologies that provide enjoyment in PE classes.

\section{CONCLUSIONS}

This study showed that positive perceptions and reasons for enjoyment in PE were to have fun, learn, like PA practice, exercise, and practice sports. Negative perceptions about PE in each school were related to the difficulty in the relationship with the teacher and to not having PE classes. The adolescents' main opinions about possible improvements in PE classes were having more diversity in PE classes and increasing the variety of types of movements, physical exercise, and sport modalities, as well as a possibility of more dynamic classes.

\section{REFERENCES}

[1] Eather N, Morgan PJ, Lubans DR. Improving health-related fitness in adolescents: the CrossFit TeensTM randomised controlled trial. J Sports Sci. 2015;0414:1-15. https://doi.org/10.1080/02640414.2015.1045925

[2] Mitchell B, McLennan S, Latimer K, Graham D, Gilmore J, Rush E. Improvement of fundamental movement skills through support and mentorship of class room teachers. Obes Res Clin Pract. 2013;7:e230-4. https://doi.org/10.1016/j. orcp.2011.11.002

[3] Minatto G, Barbosa Filho VC, Berria J, Petroski EL. School-based interventions to improve cardiorespiratory fitness in adolescents: Systematic review with meta-analysis. Sport Med. 2016;46:1273-1292. https://doi.org/10.1007/s40279016-0480-6

[4] Kolybine V. Education for a better quality of life. Hygie. 1992;11:15-17. Available: http://www.ncbi.nlm.nih.gov/ pubmed/1618511

[5] Hardman K. Physical education in schools: A global perspective. Tjelesni Odgoj U Školama Glob Pregl Stanja. 2008;40: 5-28. Available: http://0-search.ebscohost.com.library.ucc.ie/login.aspx?direct=true\&db=a9h\&AN=33115394\&site=ehost-live

[6] UNESCO. Diretrizes em educação física de qualidade (EFQ) Para Gestores de Políticas. Brasília; 2015. Available: http:// unesdoc.unesco.org/images/0023/002319/231963POR.pdf

[7] Dallolio L, Ceciliani A, Sanna T, Garulli A, Leoni E. Proposal for an enhanced physical education program in the primary school: evaluation of feasibility and effectiveness in improving physical skills and fitness. J Phys Act Health. 2016;13:1025-1034. https://doi.org/10.1123/jpah.2015-0694

[8] Giannaki CD, Aphamis G, Tsouloupas CN, Ioannou Y, Hadjicharalambous M. An eight week school-based intervention with circuit training improves physical fitness and reduces body fat in male adolescents. J Sports Med Phys Fitness. 2016;56:894-900. 
[9] Oliveira LCV de, Braga FCC, Lemes VB, et al. Effect of an intervention in Physical Education classes on health related levels of physical fitness in youth. Rev Bras Atividade Física Saúde. 2017;22:46-53. https://doi.org/10.12820/rbafs.v.22n1p46-53

[10] Villa-González E, Ruiz JR, Mendoza JA, et al. Effects of a school-based intervention on active commuting to school and health-related fitness. BMC Public Health. 2017;17:20. https://doi.org/10.1186/s12889-016-3934-8

[11] Seabra AA, Katzmarzyk P, Carvalho MJ, et al. Effects of 6-month soccer and traditional physical activity programmes on body composition, cardiometabolic risk factors, inflammatory, oxidative stress markers and cardiorespiratory fitness in obese boys. J Sport Sci. 2016;34:1822-1829. https://doi.org/10.1080/02640414.2016.1140219

[12] Vasconcellos F, Seabra A, Cunha F, et al. Health markers in obese adolescents improved by a 12-week recreational soccer program: A randomised controlled trial. J Sports Sci. 2016;34: 564-575. https://doi.org/10.1080/02640414.2015.1064150

[13] Al-Khudairy L, Loveman E, Colquitt JL, et al. Diet, physical activity and behavioural interventions for the treatment of overweight or obese adolescents aged 12 to 17 years. Cochrane Database Syst Rev. 2017;2017:CD012691. https://doi. org/10.1002/14651858.CD012691

[14] Cañadas L, Ruiz JR, Veiga OL, et al. Obese and unfit students dislike physical education in adolescence : myth or truth ? The AVENA and UP \& DOWN studies. Nutr Hosp. 2014;30:1319-1323. https://doi.org/10.3305/nh.2014.30.6.7817

[15] Ghekiere A, Van Cauwenberg J, Carver A, et al. Psychosocial factors associated with children's cycling for transport: A cross-sectional moderation study. Prev Med (Baltim). 2016;86:141-146. https://doi.org/10.1016/j.ypmed.2016.03.001

[16] Nahas M, Goldfine B, Collins M. Determinants of physical activity in adolescents and young adults: the basis for high school and college physical education to promote active lifestyles. Phys Educ. 2003;60:42-56. Available: http://media. proquest.com.ezproxy.cul.columbia.edu/media/pq/classic/doc/323407361/fmt/pi/rep/

[17] Timken G, McNamee J, Coste S. 'It doesn't seem like PE and I love it.' Eur Phys Educ Rev. 2017;1356336X1770638. https://doi.org/10.1177/1356336X17706382

[18] Hilland TA, Ridgers ND, Stratton G, Fairclough SJ. Associations between selected demographic, biological, school environmental and physical education based correlates, and adolescent physical activity. Pediatr Exerc Sci. 2011;23: 61-71. https://doi.org/10.1123/pes.23.1.61

[19] Timpka S, Petersson IF, Englund M. The grade in physical education in adolescence as predictor for musculoskeletal pain diagnoses three decades later. Pain. 2010;150: 414-419. https://doi.org/10.1016/j.pain.2010.03.035

[20] Timken GL, McNamee J. New Perspectives for teaching physical education: preservice teachers' reflections on outdoor and adventure education. J Teach Phys Educ. 2012;31:21-38. https://doi.org/10.1123/jtpe.31.1.21

[21] Spessato B, Gabbard C, Valentini NC. Perceived competence, motor performance, and body mass index: A study of Brazilian children. J Sport Exerc Psychol. 2012;34:S176.

[22] Pansera SM, Valentini NC, de Souza MS, Berleze A. Motivação intrínseca e extrínseca: Diferenças no sexo e na idade. Psicol Esc e Educ. 2016;20:313-320. https://doi.org/10.1590/2175-353920150202972

[23] Blinde EM, McCallister SG. Women, disability, and sport and physical fitness activity: the intersection of gender and disability dynamics. Res Q Exerc Sport. 1999;70:303-312. https://doi.org/10.1080/02701367.1999.10608049

[24] Healy LC, Ntoumanis N, Veldhuijzen van Zanten JJ, Paine N. Goal striving and well-being in sport: the role of contextual and personal motivation. J Sport Exerc Psychol. 2014;36:446-459. https://doi.org/10.1123/jsep.2013-0261

[25] Murcia JA, Hellín P, Cutre DG, Galindo CM. Influence of perceived sport competence body attractiveness on physical activity and other healthy lifestyle habits in adolescents. Span J Psychol. 2011;14: 282-292. https://doi.org/10.5209/ rev SJOP.2011.v14.n1.25

[26] Guedes DP, Netto JES. Motivos para a prática de esportes em atletas-jovens e fatores associados doi: 10.4025/ reveducfis.v24i1.14695. Revista da Educação Física/UEM; 2013,21-31. https://doi.org/10.4025/reveducfis.v24i1.14695

[27] Rodrigues AL de P, Santos RV dos. Aspectos Motivacionais para a Prática de Musculação entre jovens de 18 a 25 anos do munícipio de Fortaleza-CE. Rev Bras Prescrição e Fisiol do Exerc. 2016;10:308-313.

[28] Taylor IM, Lonsdale C. Cultural differences in the relationships among autonomy support, psychological need satisfaction, subjective vitality, and effort in British and Chinese physical education. J Sport Exerc Psychol. 2010;32: 655-673. https://doi.org/10.1123/jsep.32.5.655

[29] Gonçalves H, Hallal PC, Amorim TC, Araújo CLP, Menezes AMB. Fatores socioculturais e nível de atividade física no início da adolescência. Rev Panam Salud Pública. 2007;22:246-253. https://doi.org/10.1590/S1020-49892007000900004

[30] Vergara FV, Santibáñez MA, Herrera OA, et al. Motivaciones y barreras que condicionan la adherencia de escolares obesos a un programa de ejercicio físico de fuerza muscular. Resultados de un estudio cualitativo. Rev Esp Nutr Comunitaria. 2012;18: 205-210. Available: http://pesquisa.bvsalud.org/portal/resource/pt/ibc-129120

[31] Nuñez P, Picada HFS de L, Schulz ST, Habitante CA, Silva JVP da. Motivos que levam adolescentes a praticarem futsal. Conex Rev da Fac Educ Física da UNICAMP. 2008;6:67-78. https:/doi.org/10.20396/conex.v6i1.8637872

[32] Standage M. A test of self-determination theory in school physical education. Br J Educ Psychol. 2005;44:1-40. https:// doi.org/10.1348/000709904X22359

[33] Lemes VB, Brand C, Dias AF, Moreira RB, Gaya AA, Gaya AA. Preferências De Atividade Física E Esportes Para Escolares No Ensino Fundamental. Rev Kines. 2016;34:3-16. https://doi.org/10.5902/2316546422291

[34] Ling J, Robbins LB, McCarthy VL, Speck BJ. Psychosocial determinants of physical activity in children attending afterschool programs. Nurs Res. 2015;64:190-199. https://doi.org/10.1097/NNR.0000000000000084

[35] Duda JL, Nicholls JG. Dimensions of achievement motivation in schoolwork and sport. J Educ Psychol. 1992;84: 290-299. https://doi.org/10.1037/0022-0663.84.3.290

[36] Gaya A. Projetos de Pesquisa Científica e Pedagógica.O desafio da iniciação científica. 1st ed. Física C da E, editor Belo Horizonte: Instituto Casa da Educação Física; 2016.

[37] Association WM. World Medical Association Declaration of Helsinki: Ethical Principles for Medical Research Involving Human Subjects. JAMA. 2013;310:1-5. https://doi.org/10.1001/jama.2013.281053

[38] INEP. Índice de desenvolvimento da educação básica - IDEB. 2017, 1. Available: http://ideb.inep.gov.br/resultado/ resultado/resultado.seam?cid $=1393309$ 
[39] Bardin L. Summary for Policymakers. In: Intergovernmental Panel on Climate Change, editor. Climate Change 2013 - The Physical Science Basis. Cambridge: Cambridge University Press; 2011, 1-30. https://doi.org/10.1017/ CBO9781107415324.004

[40] Câmara RH. Análise de conteúdo: da teoria à pratica. Gerais Rev Interinstitucional Psicol. 2013;6: 179-191. Available: http://pepsic.bvsalud.org/pdf/gerais/v6n2/v6n2a03.pdf

[41] Moreira CH, Maciel LFP, Nascimento RK do, Folle A. Motivação de estudantes nas aulas de educação física: um estudo de revisão. Rev Corpoconsciência. 2017;21:67-79.

[42] Moore EWG, Fry MD. Physical Education Students' Ownership, Empowerment, and Satisfaction with PE and Physical Activity. Res Q Exerc Sport. 2017;88: 468-478. https://doi.org/10.1080/02701367.2017.1372557

[43] Bekiari A. Perceptions of instructor's verbal aggressiveness and physical education students' affective learning. Percept Mot Skills. 2012;115: 325-335. https://doi.org/10.2466/06.11.16.PMS.115.4.325-335

[44] Nicaise V, Bois JE, Fairclough SJ, Amorose AJ, Cogérino G. Girls' and boys' perceptions of physical education teachers' feedback: Effects on performance and psychological responses. J Sports Sci. 2007;25:915-926. https://doi. org/10.2466/06.11.16.PMS.115.4.325-335

[45] Gutiérrez M, Ruiz LM. Perceived motivational climate, sportsmanship, and students' attitudes toward physical education classes and teachers. Percept Mot Skills. 2009;108:308-326. https://doi.org/10.2466/pms.108.1.308-326 i:10.2466/pms.108.1.308-326

[46] Cox AE, Duncheon N, McDavid L. Peers and teachers as sources of relatedness perceptions, motivation, and affective responses in physical education. Res Q Exerc Sport. 2009;80:765-773. https://doi.org/10.1080/02701367.2009.10 599618 